\title{
Isolation, molecular characterization and prevalence of Clostridium perfringens in sheep and goats of Kashmir Himalayas, India
}

\author{
Salik Nazki ${ }^{1,2}$, Shakil A. Wani ${ }^{1}$, Rafia Parveen ${ }^{1}$, Showkat A. Ahangar ${ }^{1}$, Zahid A. Kashoo ${ }^{1}$, Syed Hamid ${ }^{3}$, Zahoor A. Dar ${ }^{1}$,
} Tanveer A. Dar ${ }^{4}$ and Pervaiz A. Dar ${ }^{1}$

1. Bacteriology Laboratory, Division of Veterinary Microbiology and Immunology, Faculty of Veterinary Sciences and Animal Husbandry, SKUAST-Kashmir, Shuhama, Srinagar - 190 006, Jammu and Kashmir, India; 2. Laboratory of Veterinary Immunology, College of Veterinary Medicine, Chonbuk National University, Iksan 54596, South Korea;

3. Bacteriology Laboratory, Division of Veterinary Microbiology and Immunology, Faculty of Veterinary Sciences and Animal Husbandry, SKUAST-Jammu, R.S. Pora, Jammu - 181 102, India; 4. Division of Veterinary Pathology, Faculty of Veterinary Sciences and Animal Husbandry, SKUAST-Kashmir, Shuhama, Srinagar - 190 006, Jammu and Kashmir, India. Corresponding author: Salik Nazki, e-mail: saliknazki@yahoo.co.in

Co-authors: SAW: shakilwani@gmail.com, RP: dr.rafia9549@gmail.com, SAA: ahmadshowkat160@yahoo.in, ZAK: zahidkashoo@gmail.com, SH: syedhamydh@gmail.com, ZAD: zahoorvet30@gmail.com,

TAD: drtanveer8666@gmail.com,PAD: dar.pervaiz@gmail.com

Received: 13-09-2017, Accepted: 21-11-2017, Published online: 22-12-2017

doi: 10.14202/vetworld.2017.1501-1507 How to cite this article: Nazki S, Wani SA, Parveen R, Ahangar SA, Kashoo ZA, Hamid S, Dar ZA, Dar TA, Dar PA (2017) Isolation, molecular characterization and prevalence of Clostridium perfringens in sheep and goats of Kashmir Himalayas, India, Veterinary World, 10(12):1501-1507.

\begin{abstract}
Aim: The study was conducted to report the occurrence of the Clostridium perfringens in sheep and goats of the Kashmir valley for the $1^{\text {st }}$ time and to characterize them molecularly with respect to toxin genes to determine the prevalence of the various toxinotypes.

Materials and Methods: A total of 177 samples (152 from sheep and 25 from goats) collected from healthy, diarrheic animals, and morbid material of animals suspected to have died of enterotoxaemia were screened for $C$. perfringens toxinotypes. The presumptive positive isolates were confirmed using $16 \mathrm{~S}$ rRNA gene-based polymerase chain reaction (PCR). All the confirmed isolates were screened for six toxin genes, namely; $c p a, c p b$, etx, cpi, cpb2, and $c p e$ using a multiplex PCR.

Results: The PCR amplification of 16S rRNA gene revealed that out of 177 samples collected, 125 (70.62\%) were found positive for $C$. perfringens, of which $110(72.36 \%)$ were from sheep and $15(60 \%)$ were from goats. The highest prevalence of $C$. perfringens toxinotype $\mathrm{D}$ was observed in lambs $(56.16 \%)$ and kids $(46.16 \%)$ followed by $3.84 \%$ in adult sheep while it was absent in samples obtained from adult goats. The multiplex PCR revealed that $67(60.90 \%)$ isolates from sheep and $8(53.33 \%)$ isolates from goats belonged to toxinotype A, while $43(39.09 \%)$ isolates from sheep and $7(46.66 \%)$ isolates from goats were detected as toxinotype $\mathrm{D}$. None of the isolates was found to be toxinotype $\mathrm{B}, \mathrm{C}$, or E. All the C. perfringens toxinotype A isolates from sheep were negative for both $c p b 2$ and cpe genes, however, $27.90 \%$ toxinotype $\mathrm{D}$ isolates from sheep carried $c p b 2$ gene, and $6.97 \%$ possessed cpe gene. In contrast, $12.50 \%$. perfringens toxinotype A isolates from goats harbored $c p b 2$ and cpe genes while $14.28 \%$ isolates belonging to toxinotype D carried $c p b 2$ and cpe genes, respectively.
\end{abstract}

Conclusion: The high prevalence of $C$. perfringens was observed, even in day-old lambs. The toxinotypes A and D are prevalent in both sheep and goats. The severity of disease and mortality may be associated with the presence of minor toxins in both the detected toxinotypes.

Keywords: Clostridium perfringens, enterotoxemia, multiplex polymerase chain reaction, toxinotype, 16S rRNA.

\section{Introduction}

Clostridium perfringens is one of the ubiquitous organisms among clostridial species. It is the common inhabitant of the gastrointestinal tract of humans and animals and also occurs in the soil. It is relatively aero-tolerant, spore-forming, non-motile, and Grampositive rods $(0.6-0.8 \times 2-4 \mu \mathrm{m})$ [1]. On the basis of four major toxins, namely, alpha (CPA), beta (CPB),

Copyright: Nazki, et al. Open Access. This article is distributed under the terms of the Creative Commons Attribution 4.0 International License (http://creativecommons.org/licenses/by/4.0/), which permits unrestricted use, distribution, and reproduction in any medium, provided you give appropriate credit to the original author(s) and the source, provide a link to the Creative Commons license, and indicate if changes were made. The Creative Commons Public Domain Dedication waiver (http://creativecommons.org/ publicdomain/zero/1.0/) applies to the data made available in this article, unless otherwise stated. epsilon (ETX), and iota (ITX), the C. perfringens is divided into five toxinotypes, i.e. $\mathrm{A}, \mathrm{B}, \mathrm{C}, \mathrm{D}$, and $\mathrm{E}[2,3]$. The specific toxins are responsible for the clinical signs and a syndrome attributable to each type. The specific enteric infections of various animal species are associated to different toxinotypes [4,5].

All the five toxinotypes produce alpha toxin and in addition to that toxinotype $\mathrm{B}$ produces beta and epsilon-toxin while toxinotype $\mathrm{C}$ produces beta-toxin, toxinotype D produces epsilon-toxin, and toxinotype E strains produce iota-toxin. Along with major toxins, $C$. perfringens toxinotypes also produce some minor toxins such as enterotoxin (CPE) and beta2 toxin (CPB2) [6]. Isolates of $C$. perfringens carrying the gene for beta2 toxin have been identified, suggesting a role for beta2-toxin in caprine enterotoxemia and a common cause of death in growing kids $[7,8]$. The 
C. perfringens toxinotype $\mathrm{D}$ is of utmost importance in case of sheep and goats, responsible for ovine enterotoxemia and caprine enterocolitis, respectively. Enterotoxemia is an acute, highly fatal intoxication that affects sheep, lambs, kids, and goats [9]. Sheep of all ages are affected by enterotoxemia, but lambs under 10 weeks of age are most susceptible as they are nursed by heavy-lactating ewes and the weaned lambs on lush pasture or in feedlots $[10,11]$.

Enterotoxemia results in the colossal economic losses to the farming industry worldwide [12]. In $2010-2011$, livestock generated a total of $4 \%$ of the gross domestic product (GDP) and $26 \%$ of the agricultural GDP in India. Sheep rearing is considered to be one of the major contributors to the livestock sector. The economics of sheep farming depends largely on the survival of the lambs and later lambing percentage of adult stock. A study showed that enterotoxemia (incidence rate $-1.5 \%$, death rate $-2.4 \%$, and case fatality rate $-30.8 \%$ ) comes next to diseases such as bluetongue, PPR, and anthrax with respect to incidence and death rate in India [13].

The present study was conducted for a period of 6 months (October 2014 to April 2015) to investigate the prevalence of $C$. perfringens, in sheep and goats of Kashmir valley as well as characterize the genotype of its isolates. In spite of its heavy impact on sheep rearing farms, there seems no literature available on any aspect of $C$. perfringens toxinotype D in the Kashmir Himalayas, India. This study documented the presence of $C$. perfringens toxinotype A and D in sheep and goats for the $1^{\text {st }}$ time in Kashmir.

\section{Materials and Methods \\ Ethical approval}

The approval from the Institutional Animal Ethics Committee to carry out this study was not required as no invasive technique was used. The fecal samples were collected from healthy, clinically affected with enterotoxemia and dead animals as per standard collection procedure.

\section{Samples}

A total of 177 samples comprising fecal material, and intestinal contents, kidneys, and abomasum pieces from animals suspected to have been died due to enterotoxemia were collected from 152 sheep and 25 goats. The samples were collected from organized sheep farms and unorganized sectors such as local farmers rearing sheep and goats. Out of the 152 samples of sheep, fecal material was collected from healthy (125) and diarrheic (21) sheep while kidneys, abomasum pieces and intestinal contents were collected from 6 carcasses. Among goats, fecal samples were collected from healthy (20) and diarrheic (3) goats while kidneys and intestinal contents were collected from 2 dead animals. The samples were collected within 2 hours after death of animals. The samples were collected in sterile vials from animals of different age groups.

\section{Isolation and identification of $\boldsymbol{C}$. perfringens}

For isolation of $C$. perfringens, samples were inoculated in Difco ${ }^{\mathrm{TM}}$ Cooked meat medium (Becton, Dickinson and Company, Sparks, MD, USA) and incubated anaerobically in 3.5 litre anaerobic jar (Oxoid Limited, Thermo Fisher Scientific Inc., UK) with GasPak ${ }^{\mathrm{TM}}$ Anaerobe Container System (Becton, Dickinson and Company, Sparks, MD, USA) at $37^{\circ} \mathrm{C}$ for $24 \mathrm{~h}$. Enriched samples were streaked on Sulfite Polymyxin Sulfadiazine agar plates (SPS $\mathrm{HiVeg}^{\mathrm{TM}}$ Agar, Modified; HiMedia laboratories, Mumbai, India) and the plates were incubated anaerobically at $37^{\circ} \mathrm{C}$ for $24 \mathrm{~h}$. After incubation suspected colonies were sub-cultured on the SPS agar plates until they were free from contaminating bacteria. The pure cultures of $C$. perfringens toxinotypes were lyophilized for future use in the laboratory using $0.25 \mathrm{M}$ sucrose as a cryoprotectant.

Confirmation of the isolates was done by demonstration of the typical cellular morphology in Gram's stained smear, standard biochemical tests [14] and detection of $C$. perfringens by species-specific polymerase chain reaction (PCR) using $16 \mathrm{~S}$ rRNA gene primers $[15,16]$.

\section{Molecular characterization of $\boldsymbol{C}$. perfringens isolates}

\section{Bacterial DNA isolation}

Suspected isolated colonies from agar plates were suspended in $1.5 \mathrm{ml}$ microcentrifuge tubes containing $100 \mu \mathrm{l}$ of distilled water by gentle vortexing. The samples were boiled for $5 \mathrm{~min}$, cooled on ice for $10 \mathrm{~min}$ and centrifuged at $10,000 \times \mathrm{g}$ in a tabletop microcentrifuge (Cooling Centrifuge, Eppendorf 5418R, Hamburg, Germany) for 1 min. 3 microliters $(\mu 1)$ of the supernatant were used as the template for PCR.

\section{$P C R$}

All the PCR assays in this study were performed in $25 \mu \mathrm{l}$ reaction volume in Mastercycler gradient (Eppendorf AG, Hamburg, Germany). The reaction consisted of $3.0 \mu \mathrm{l}$ template DNA, $2.5 \mu \mathrm{l}$ of $10 \times$ buffer, $0.2 \mu \mathrm{l}$ of $25 \mathrm{mM}$ dNTP mix, $1 \mathrm{U}$ of Taq DNA Polymerase (Fermentas Life Sciences) and sterile distilled water. The $\mathrm{MgCl}_{2}$ was used at $2.0 \mathrm{mM}$ concentration unless otherwise indicated. Sterilized distilled water was used as negative controls. All the primers were acquired from GCC Biotech, Kolkata, India.

\section{$16 S$ rRNA gene amplification}

The species-specific primers (Table-1) $[15,17]$ targeting $16 \mathrm{~S}$ rRNA gene of the $C$. perfringens was used. The PCR conditions consisted of initial denaturation at $95^{\circ} \mathrm{C}$ for $15 \mathrm{~min}$, followed by 35 cycles of denaturation at $94^{\circ} \mathrm{C}$ for $30 \mathrm{~s}$, annealing at $49^{\circ} \mathrm{C}$ for 90 $\mathrm{s}$, and extension at $72^{\circ} \mathrm{C}$ for $90 \mathrm{~s}$. This was followed by final extension at $72^{\circ} \mathrm{C}$ for $10 \mathrm{~min}$. The DNA of C. perfringens type D isolates obtained from Sheep Husbandry Department was used as positive control. 
Table-1: List of primers used in PCR for amplification of Clostridium perfringens toxin genes.

\begin{tabular}{|c|c|c|c|c|}
\hline Target gene & Primer sequence $\left(5^{\prime}-3^{\prime}\right)$ & Primer conc. $(\mu \mathrm{M})$ & Product size (bp) & References \\
\hline 16S rRNA & $\begin{array}{l}\text { F- TAACCTGCCTCATAGAGT } \\
\text { R-TTTCACATCCСАCTTAATC }\end{array}$ & 0.4 & 481 & {$[15]$} \\
\hline cpa & $\begin{array}{l}\text { F-GCTAATGTTACTGCCGTTGA } \\
\text { R-CCTCTGATACATCGTGTAAG }\end{array}$ & 0.4 & 324 & {$[17]$} \\
\hline$c p b$ & $\begin{array}{l}\text { F-GCGAATATGCTGAATCATCA } \\
\text { R-GCAGGAACATTAGTATATCTTC }\end{array}$ & 0.4 & 195 & {$[17]$} \\
\hline etx & $\begin{array}{l}\text { F-TGGGAACTTCGATACAAGCA } \\
\text { R-AACTGCACTATAATTTCCTITCC }\end{array}$ & 0.4 & 376 & {$[17]$} \\
\hline cpi & $\begin{array}{l}\text { F-AATGGTCCTITAAATAATCC } \\
\text { R-TTAGCAAATGCACTCATATT }\end{array}$ & 0.4 & 272 & [17] \\
\hline$c p b 2$ & $\begin{array}{l}\text { F-AAATATGATCCTAACCAACAA } \\
\text { R-CCAAATACTCTAATYGATGC }\end{array}$ & 0.4 & 548 & {$[17]$} \\
\hline cpe & $\begin{array}{l}\text { F-TTCAGTTGGATTTACTTCTG } \\
\text { R-TGTCCAGTAGCTGTAATTGT }\end{array}$ & 0.4 & 485 & {$[17]$} \\
\hline
\end{tabular}

$\mathrm{PCR}=$ Polymerase chain reaction

\section{Multiplex PCR of virulent genes}

The $C$. perfringens isolates were characterized for important virulence factors including $c p a, c p b$, etx, cpi, cpb2, and cpe. All the C. perfringens isolates were screened for these toxin genes using a multiplex PCR. These six toxin genes include $\alpha$-toxin (cpa), $\beta$-toxin $(c p b), \varepsilon$-toxin (etx), í-toxin (cpi), $\beta 2$-toxin ( $c p b-2)$, and enterotoxin (cpe). The primers used for the amplification of the genes are shown in Table-1. The PCR conditions were similar to that used for amplification of 16S rRNA gene except for the annealing temperature that was set at $53^{\circ} \mathrm{C}$. The amplified products were electrophoresed in 1.5\% agarose gel (Sigma-Aldrich, St. Louis, USA) and stained with ethidium bromide $(0.5 \mu \mathrm{g} / \mathrm{ml})$. Amplified bands were visualized and photographed under UV illumination (Ultra Cam Digital Imaging, Ultra. Lum. Inc., Claremont, CA).

\section{Results}

Detection and prevalence of $C$. perfringens toxinotypes from samples

From 152 samples of sheep, $110(72.36 \%)$ carried $C$. perfringens while, out of 25 samples from goats, $15(60 \%)$ revealed the presence of C. perfringens. Out of 125 samples collected from healthy sheep, $86(68.80 \%)$ were positive for $C$. perfringens, while $19(90.47 \%)$ out of 21 enterotoxemia suspected live sheep and $5(83.33 \%)$ out of 6 enterotoxemia suspected dead sheep were detected positive for $C$. perfringens. Among goats, $11(55 \%)$ out of 20 healthy goats were detected positive for $C$. perfringens while $2(66.66 \%)$ out of 3 diarrheic goats and both dead goats were positive for $C$. perfringens. All the 110 isolates from sheep and 15 isolates from goats were morphologically and biochemically identified by Gram staining, capsular staining, lecithinase activity on egg yolk agar media, triple sugar iron (TSI) test, and formation of double zone of hemolysis on 5\% sheep blood agar (Figure-1) as $C$. perfringens. These isolates amplified $481 \mathrm{bp}$ PCR product (Figure-2) corresponding to C. perfringens.

Out of a total of 110 isolates from sheep, $67(60.90 \%)$ were found to carry cpa gene alone as a

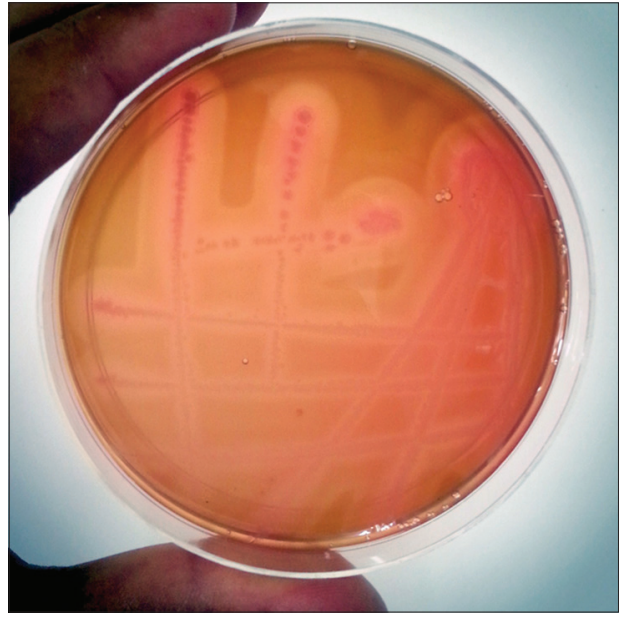

Figure-1: Double zone of hemolysis produced by Clostridium perfringens on sheep blood agar.

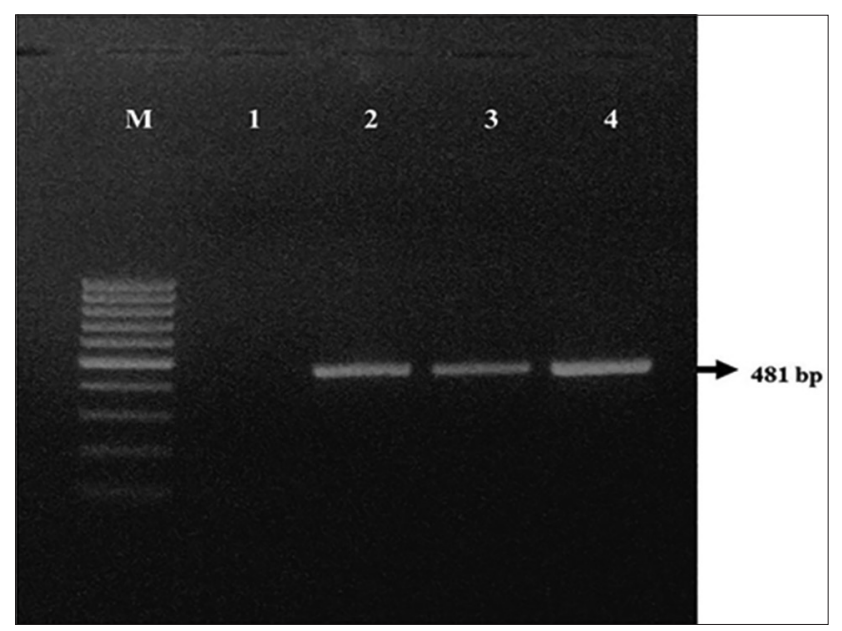

Figure-2: 481 bp amplicon characteristic of $16 \mathrm{~S}$ rRNA gene of Clostridium perfringens. Lane M: 100 bp DNA ladder. Lane 1: Negative control. Lane 2: Positive control. Lanes 3-4: Isolates positive for $C$. perfringens.

major toxin gene, thus were designated as toxinotype A. While the remaining $43(39.09 \%)$ harbored both cpa and etx genes, thus were designated as toxinotype $\mathrm{D}$. Among 86 isolates from healthy sheep, 60 (69.77\%) isolates were tested to be positive for toxinotype A while $26(30.23 \%)$ were found to be toxinotype D. 
Table-2: Clostridium perfringens toxinotype distribution among healthy and enterotoxemia suspected sheep and goats.

\begin{tabular}{|c|c|c|c|c|c|c|}
\hline \multirow[t]{3}{*}{ Toxinotype } & \multicolumn{6}{|c|}{ Species } \\
\hline & \multicolumn{2}{|c|}{ Sheep } & \multirow[t]{2}{*}{$\mathbf{N}$} & \multicolumn{2}{|c|}{ Goat } & \multirow[t]{2}{*}{$\mathbf{N}$} \\
\hline & ET suspected (\%) & Healthy (\%) & & ET suspected (\%) & Healthy (\%) & \\
\hline$A$ & $7(29.16)$ & $60(69.77)$ & $67(60.91)$ & $2(50)$ & $6(54.54)$ & $8(53.33)$ \\
\hline D & $17(70.84)$ & $26(30.23)$ & $43(39.09)$ & $2(50)$ & $5(45.46)$ & $7(46.67)$ \\
\hline Total & 24 & 86 & 110 & 4 & 11 & 15 \\
\hline
\end{tabular}

Out of total 24 isolates from sheep suffering diarrhea or suspected to have died of enterotoxemia, $7(29.16 \%)$ isolates were found to be toxinotype A while $17(70.84 \%)$ isolates were detected as toxinotype D (Table-2). C. perfringens toxinotype D was isolated from kidneys, intestinal contents and abomasum of 4 dead sheep while remaining 2 showed the presence of toxinotype A. None of the isolates carried $c p b$ or cpi genes indicating the absence of $C$. perfringens toxinotype $\mathrm{B}, \mathrm{C}$, or $\mathrm{E}$ in sheep samples. In case of goats, out of 15 isolates, $8(53.33 \%)$ were detected as toxinotype A as they carried cpa gene alone and the remaining $7(46.66 \%)$ as toxinotype D which carried both cpa and etx genes. From 11 isolates of healthy goats, $6(54.54 \%)$ isolates were detected as toxinotype A while $5(45.46 \%)$ isolates were confirmed to be toxinotype D. Among 4 isolates from goats suffering diarrhea or suspected to have died of enterotoxemia, $2(50 \%)$ were confirmed as toxinotype A and $2(50 \%)$ as toxinotype D. C. perfringens toxinotype D was isolated from kidneys, intestinal contents and abomasum of both dead goats. None of the isolates possessed $c p b$ or cpi genes indicating the absence of $C$. perfringens toxinotype B, C, or E in goat samples (Figure-3).

Further, the sheep samples were collected from both organized as well as unorganized sectors. Out of the total of 89 isolates from organized sector, $48(53.93 \%)$ isolates were detected as toxinotype A while the remaining $41(46.06 \%)$ isolates were found as toxinotype D (Table-3). Among the 21 isolates from unorganized sector, $19(90.47 \%)$ isolates were toxinotype A while $2(9.52 \%)$ isolates were toxinotype D. The occurrence of toxinotype D was found to be higher in organized sector $(46.06 \%)$ than that of unorganized sector $(9.52 \%)$.

\section{Identification of $C$. perfringens toxinotypes carrying minor toxin genes}

In sheep, among $C$. perfringens toxinotype A isolates none of the isolates carried $c p b 2$-gene or cpe-gene in addition to the species-specific cpa gene. Among $C$. perfringens toxinotype D isolates, $12(27.90 \%)$ were positive for $c p b 2$ and $3(6.97 \%)$ harbored cpe-gene in addition to the cpa and etx genes. Out of 24 isolates from sheep suspected of enterotoxemia, $4(16.66 \%)$ carried cpb2 while $2(8.34 \%)$ were detected positive for cpe gene in toxinotype D. Among healthy sheep, $8(9.30 \%)$ carried cpb2 while $1(1.17 \%)$ isolate harbored cpe gene in toxinotype D out of 86 isolates (Table-4).
Table-3: Prevalence of Clostridium perfringens toxinotypes in sheep under organized and unorganized rearing conditions.

\begin{tabular}{lccc}
\hline Sampling area & $\begin{array}{c}\text { Total } \\
\text { number of } \\
\text { isolates }\end{array}$ & \multicolumn{2}{c}{ Toxinotypes } \\
\cline { 3 - 4 } & $\mathbf{N}$ & $\mathbf{A}(\mathbf{\%})$ & $\mathbf{N}$ \\
& 89 & $48(53.93)$ & $41(46.06)$ \\
\hline Organized sector & 81 & $19(90.47)$ & $2(9.52)$ \\
Unorganized sector & 21 & $67(60.90)$ & $43(39.09)$ \\
\hline
\end{tabular}

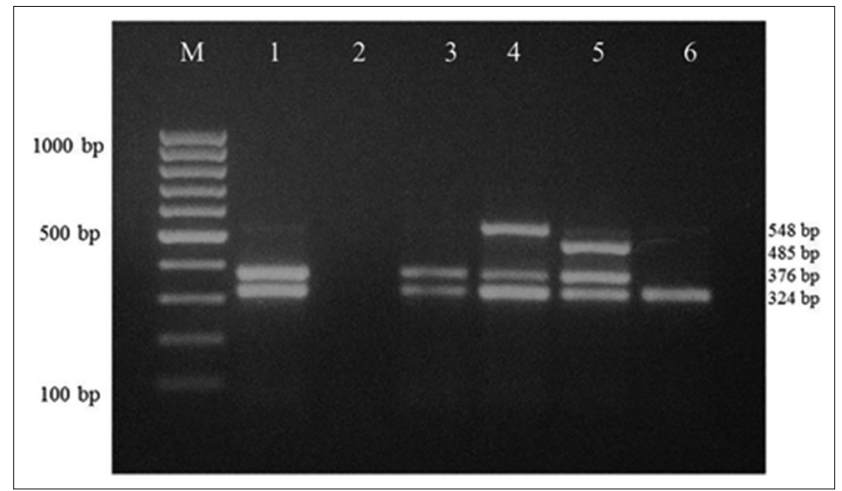

Figure-3: Multiplex polymerase chain reaction amplicons of different virulence genes of Clostridium perfringens. Lane M: 100 bp DNA ladder. Lane 1: Positive control of C. perfringens Type $\mathrm{D}$ with amplified cpa (324 bp) and etx (376 bp) genes. Lane 2: Negative control. Lane 3: C. perfringens Type D. Lane 4: C. perfringens Type D with amplified $c p a$, etx and beta2 (548 bp) genes. Lane 5: C. perfringens Type $\mathrm{D}$ with amplified $c p a$, etx, and cpe (485 bp) genes. Lane 6: C. perfringens Type A with cpa gene amplification.

In case of goats among $C$. perfringens toxinotype A, one (12.50\%) isolate each carried either $c p b 2$ gene or cpe-gene in addition to cpa gene. Both these isolates were acquired from samples of goats suspected of suffering enterotoxemia. Among C. perfringens toxinotype D isolates, one (14.28\%) isolate was positive for $c p b 2$ and one (14.28\%) harbored cpe-gene in addition to the cpa and etx genes. Isolates carrying cpb2 and cpe gene were detected in healthy goats.

Among lambs, the occurrence of toxinotype D $(56.16 \%)$ was higher than that $(28.76 \%)$ of toxinotype A (Table-5). In case of weaners, $55.55 \%$ carried toxinotype A while none of the samples from weaners revealed the presence of toxinotype $\mathrm{D}$ of $C$. perfringens. Among adult sheep occurrence of toxinotype A $(59.61 \%)$ was higher than that $(3.84 \%)$ of toxinotype D.

In case of kids occurrence of toxinotype D $(46.16 \%)$ was higher than that $(15.38 \%)$ of 
Table-4: Distribution of major and minor toxin genes in Clostridium perfringens toxinotypes isolated from healthy and enterotoxemia suspected sheep and goats.

\begin{tabular}{|c|c|c|c|c|c|c|c|}
\hline \multirow[t]{3}{*}{ Toxinotype } & \multicolumn{7}{|l|}{ Species } \\
\hline & \multirow[t]{2}{*}{ Toxin genes } & \multicolumn{3}{|c|}{ Sheep } & \multicolumn{3}{|c|}{ Goat } \\
\hline & & $\begin{array}{c}\text { ET } \\
\text { suspected (\%) }\end{array}$ & Healthy (\%) & N (\%) & $\begin{array}{c}\text { ET } \\
\text { suspected (\%) }\end{array}$ & Healthy (\%) & N (\%) \\
\hline \multirow[t]{3}{*}{ A } & сра & $7(29.16)$ & 60 (69.77) & $67(100)$ & $0(0.00)$ & $6(54.54)$ & $6(75.00)$ \\
\hline & $c p a$ and $c p b 2$ & $0(0.00)$ & $0(0.00)$ & $0(0.00)$ & $1(25.00)$ & $0(0.00)$ & $1(12.50)$ \\
\hline & $\begin{array}{l}\text { cpa and cpe } \\
\mathrm{N}\end{array}$ & $0(0.00)$ & $0(0.00)$ & $\begin{array}{c}0(0.00) \\
67\end{array}$ & $1(25.00)$ & $0(0.00)$ & $\begin{array}{c}1(12.50) \\
8\end{array}$ \\
\hline \multirow[t]{4}{*}{ D } & cpa and etx & $11(45.84)$ & $17(19.76)$ & $28(65.11)$ & $2(50.00)$ & $3(27.28)$ & $5(71.42)$ \\
\hline & $c p a$, etx and $c p b 2$ & $4(16.66)$ & $8(9.30)$ & $12(27.91)$ & $0(0.00)$ & $1(9.09)$ & $1(14.28)$ \\
\hline & cpa, etx and cpe & $2(8.34)$ & $1(1.17)$ & $3(6.98)$ & $0(0.00)$ & $1(9.09)$ & $1(14.28)$ \\
\hline & $\mathrm{N}$ & 24 & 86 & 43 & 4 & 11 & 7 \\
\hline
\end{tabular}

Table-5: Age-wise distribution of Clostridium perfringens toxinotypes in sheep and goats.

\begin{tabular}{llccc}
\hline Species & Age & Total samples & \multicolumn{2}{c}{ Toxinotypes } \\
\cline { 3 - 5 } & & & $\mathbf{A}(\%)$ & $\mathbf{N}(\mathbf{0})$ \\
\hline Sheep & Lambs (0-3 months) & 73 & $21(28.76)$ & $41(56.16)$ \\
& Weaners (3-12 months) & 27 & $15(55.55)$ & $0(0.00)$ \\
& Adults (1 year or more) & 52 & $31(59.61)$ & $2(3.84)$ \\
Goats & Kids (0-6 months) & 13 & $2(15.38)$ & $6(46.16)$ \\
& Adults (more than 6 months) & 12 & $7(8.33)$ & $0(0.00)$ \\
\hline
\end{tabular}

toxinotype A. In case of adult goats $58.33 \%$ carried toxinotype A while none of the samples from adult goats revealed presence of toxinotype $\mathrm{D}$ of $C$. perfringens.

\section{Discussion}

C. perfringens toxinotypes are responsible for varied disease syndromes in livestock animals and poultry. In this study, healthy as well as suspected sheep and goat populations from different regions of Kashmir valley were screened for the presence of $C$. perfringens toxinotypes. Our findings revealed that $110(72.36 \%)$ of 152 sheep and $15(60 \%)$ of 25 goats were positive for $C$. perfringens based on isolation and PCR amplification of 16S rRNA gene. The $C$. perfringens was isolated from both healthy and suspected enterotoxaemia cases. In accordance with our study, a lower occurrence of $24.13 \%$ of C. perfringens in sheep of Morocco [18] while as a higher prevalence of $100 \%$ of $C$. perfringens in sheep of Italy [19] has been recorded. Similarly, the prevalence of $59.62 \%$ and $75 \%$ of $C$. perfringens in sheep was reported in Andhra Pradesh, India [20]. The prevalence of $96.92 \%$ of $C$. perfringens in sheep and goats in Switzerland has been reported [21].

In this study, $C$. perfringens toxinotype $\mathrm{D}$ was more prevalent among lambs $(56.16 \%)$ and kids $(46.16 \%)$ than adult sheep (3.84\%), respectively, while none of the $C$. perfringens isolates from adult goats belonged to toxinotype D. Our findings are in agreement with a research done in fattening lambs in the United Kingdom where enterotoxemia has been reported to be more prevalent in lambs aged between
3 and 8 weeks [22]. The authors attributed it to the heavy feeding and milking of lambs by ewes that are grazed on lush pastures. However, they also observed its higher prevalence in adult animals grazed on luxurious pastures. The spillover of the carbohydrate and protein-rich nutrients into the small intestine from the abomasum encourages rapid multiplication of organisms and production of ETX. The increased prevalence of $C$. perfringens Type D $(21.65 \%)$ in lambs than healthy adult sheep (3.7\%) has been reported in Andhra Pradesh, India [20].

The organized sheep rearing farms of the valley revealed the higher occurrence of toxinotype D $(46.06 \%)$ in comparison to the unorganized sector $(9.52 \%)$. This discrepancy could be attributed to lesser availability of the samples from lambs in comparison to the adults from the unorganized sources during the study period.

In this study, out of 110 sheep, 67 (60.90\%) were found positive only for cpa toxin gene, thus belonged to toxinotype A, while the remaining 43 (39.09\%) carried both cpa and etx toxin genes thus belonged to toxinotype D. None of these isolates possessed $c p b$ or cpi toxin gene, indicating the absence of C. perfringens toxinotype B, C, or E. Similarly, in case of goats, $8(53.33 \%)$ out of 15 isolates were detected as toxinotype A and the remaining 7 (46.66\%) were toxinotype D. However, none of these isolates revealed the presence of $c p b$ or $c p i$ toxin gene, indicating the absence of $C$. perfringens toxinotype $\mathrm{B}, \mathrm{C}$, or $\mathrm{E}$. These findings are in agreement with the observations reported from Italy where $84 \%$ of C. perfringens isolated from the lambs and kids in Italy is toxinotype A 
and the remaining $16 \%$ as toxinotype $\mathrm{D}$, and none belonged to type B, C, or E [19]. In India, 69.29\% prevalence of enterotoxemia from suspected sheep flocks and $39.71 \%$ from healthy sheep flocks has been reported [20]. Genotyping of the isolates from healthy flocks indicated the presence of toxinotype A and D to be $92.59 \%$ and $7.40 \%$, respectively, and C. perfringens toxinotype A (67.01\%), toxinotype D (21.65\%) as well as type C (11.34\%) from suspected flocks. Although toxinotype $\mathrm{C}$ has not been reported from sheep or goats in the present study, the presence of toxinotype $\mathrm{B}, \mathrm{C}$, or $\mathrm{E}$ cannot be ruled out owing to the fact the study being preliminary and based comparatively on small sample size.

In addition to four major toxin genes, two minor toxin genes $c p b 2$ gene and cpe gene were detected in 19 isolates of toxinotype A and D. In sheep, all C. perfringens toxinotype $\mathrm{A}$ isolates revealed the presence of species-specific cpa gene but none of the isolates harbored $c p b 2$ or cpe-gene. However, the prevalence of $42.8 \%$ of $c p b 2$ gene among C. perfringens toxintypes A isolates in sheep in Iran has been reported by Jabbari et al. [23]. In contrast to this, $C$. perfringens toxinotype A isolates from goats carried $c p b 2$-gene $(12.50 \%)$ and cpe-gene $(12.50 \%)$. The presence of cpb2 gene in 4/21 (19\%) of toxinotype A isolates from lambs and kids has been observed in Italy [19]. The $c p b 2$ gene and cpe gene can be carried by all $C$. perfringens toxinotypes [24].

In sheep, within $C$. perfringens toxinotype D isolates, $27.90 \%$ possessed $c p b 2$-gene and $6.97 \%$ harbored cpe-gene in addition to the cpa and etx-genes. While out of seven $C$. perfringens toxinotype D isolates from goats $14.28 \%$ contained both $c p b 2$-gene and cpe-genes. Clostridium perfringens enterotoxin and beta- 2 toxin have been widely reported as potential contributors to $C$. perfringens related enteric diseases. The occurrence of $c p b 2$ gene in one out of two toxinotype $\mathrm{D}$ isolates in lambs and kids has been reported in Italy [19]. Similarly, in Iranian sheep, $69.25 \%$ of $C$. perfringens toxinotype $\mathrm{D}$ isolates possessed $\mathrm{c} p b 2$ gene [23]. While investigating C. perfringens toxinotype $\mathrm{D}$ in sheep and goats in Germany, it was observed that out of nine isolates from sheep five carried cpe gene while one out of three isolates from goats showed the presence of cpe gene [25].

\section{Conclusion}

C. perfringens is highly prevalent among lambs and kids in Kashmir valley. The toxinotype A was more prevalent than that of toxinotype $\mathrm{D}$ in sheep and goats. Absence of toxinotypes B, C, and E in the present study does not indicate the absence of these toxinotypes in the sheep and goat population as the number of samples was less. The $C$. perfringens toxinotype D is more prevalent in organized than unorganized sector and mostly affects lambs and kids. The adult sheep and goats carry $C$. perfringens but cause the disease occasionally. The present work documents the prevalence, isolation and characterization of C. perfringens toxinotype $\mathrm{D}$ in sheep and goats of Kashmir valley. The present work also makes the local strains available for vaccine formulation to effectively control the menace in the state.

\section{Authors' Contributions}

SN carried out the study. SAW planned, designed and supervised the experiment, RP and SAA provided technical support, TAD, ZAD helped in collection of samples and ZAK, SH and PAD supported in drafting the manuscript. The authors are thankful to the Sheep Husbandry Department, Jammu and Kashmir, India, for providing positive control. All authors read and approved the manuscript.

\section{Acknowledgments}

The authors wish to acknowledge the financial support provided by the Niche Area of Excellence (NAE) Programme, ICAR, New Delhi (Project number: 10(1)/2015-EP\&HS) for carrying out the research work.

\section{Competing Interests}

The authors declare that they have no competing interests.

\section{References}

1. Uzal, F.A., Songer, J.G., Prescott, J.F. and Popoff, M.R. (2016) Brief description of animal pathogenic clostridia. Clostridial Dis. Anim., John Wiley \& Sons, Inc, Hoboken, NJ. doi: 10.1002/9781118728291.ch3.

2. Siqueira, F.F., Almeida, M.O., Barroca, T.M., Horta, C.C., Carmo, A.O., Silva, R.O., Pires, P.S., Lobato, F.C. and Kalapothakis, E. (2012) Characterization of polymorphisms and isoforms of the Clostridium perfringens phospholipase $\mathrm{C}$ gene (plc) reveals high genetic diversity. Vet. Microbiol., 159(3-4): 397-405.

3. Milton, A.A.P., Agarwal, R.K., Bhuvana Priya, G., Saminathan, M., Aravind, M., Reddy, A., Athira, C.K., Ramees, T., Sharma, A.K. and Kumar A. (2017) Prevalence and molecular typing of Clostridium perfringens in captive wildlife in India. Anaerobe, 44: 55-57.

4. Ohtani, K. and Shimizu, T. (2016) Regulation of toxin production in Clostridium perfringens. Toxins (Basel), 8(7), 207.

5. Ashgan, M., Al-Arfaj, A.A. and Moussa, I. (2013) Identification of four major toxins of Clostridium perfringens recovered from clinical specimens. Afr. J. Microbiol. Res., 7, 3658-3664.

6. Silva, R.O., Almeida, L.R., Oliveira Junior, C.A., Lima, P.C., Soares, D.F., Pereira, P.L., Silva, I.J. and Lobato, F.C. (2016) Isolation and genotyping of Clostridium perfringens from free-living South American Coati (Nasua Nasua). J. Zoo Wildl. Med. 47(1): 333-336.

7. Dray, T. (2004) Clostridium perfringens Type A and Beta 2 toxin associated with enterotoxemia in a 5-week-old goat. Can. Vet. J., 45(3): 251-253.

8. Garcia, J.P., Adams, V., Beingesser, J., Hughes, M.L., Poon, R., Lyras, D., Hill, A., McClane, B.A., Rood, J,I. and Uzal FA. (2013) Epsilon toxin is essential for the virulence of Clostridium perfringens Type D infection in sheep, goats, and mice. Infect. Immun., 81(7): 2405-2414.

9. Stiles, B.G., Barth, G., Barth, H. and Popoff, M.R. (2013) Clostridium perfringens epsilon toxin: A malevolent molecule for animals and man? Toxins (Basel), 5(11): 2138-2160. 
10. Songer, J.G. (1999) Clostridial enteric diseases of domestic animals. Clin. Microbiol. Rev., 9(2): 216-234.

11. Jemal, D., Shifa, M. and Kebede, B. (2016) Review on pulpy kidney disease. J. Vet. Sci. Technol 7(5): 361.

12. Bokori-Brown, M., Hall, C.A., Vance, C., Fernandes da Costa, S.P., Savva, C.G., Naylor, C.E., Cole, A.R., Basak, A.K., Moss, D.S. and Titball, R.W. (2014) Clostridium perfringens epsilon toxin mutant Y30AY196A as a recombinant vaccine candidate against enterotoxemia. Vaccine, 32(23): 2682-2687.

13. Singh, B. and Prasad S. (2009) A model based assessment of economic losses due to some important diseases in sheep in India. Indian J. Anim. Sci., 79(12): 1265-1268.

14. Markey, B.K. (2013) Clinical Veterinary Microbiology. $2^{\text {nd }}$ ed. Elsevier, Edinburgh. p11, 901.

15. Tonooka, T., Sakata, S., Kitahara, M., Hanai, M., Ishizeki, S., Takada, M., Sakamoto, M. and Benno, Y. (2005) Detection and quantification of four species of the genus Clostridium in infant feces. Microbiol. Immunol., 49(11): 987-992.

16. Ahsani, M.R., Bafti, M.S., Esmailizadeh, A.K. and Mohammadabadi, MR. (2011) Genotyping of isolates of Clostridium perfringens from vaccinated and unvaccinated sheep. Small Ruminant Res., 95(1): 65-69.

17. van Asten, A.J, van der Wiel, C.W, Nikolaou, G, Houwers, D.J. and Grone, A.A. (2009) Multiplex PCR for toxin typing of Clostridium perfringens isolates. Vet Microbiol., 136(3-4): 411-412.

18. el Idrissi, A.H. and Ward, G.E. (1992) Evaluation of enzymelinked immunosorbent assay for diagnosis of Clostridium perfringens enterotoxemias. Vet. Microbiol., 31(4): 389-396.
19. Greco, G., Madio, A., Buonavoglia, D., Totaro, M., Corrente, M., Martella, V. and Buonavoglia, C. (2005) Clostridium perfringens toxin-types in lambs and kids affected with gastroenteric pathologies in Italy. Vet. J., 170(3): 346-50.

20. Kumar, N.V., Sreenivasulu, D. and Reddy, Y.N. (2014) Prevalence of Clostridium perfringens toxin genotypes in enterotoxemia suspected sheep flocks of Andhra Pradesh. Vet. World, 7(12): 1132-6.

21. Miserez, R., Frey, J., Buogo, C., Capaul, S., Tontis, A., Burnens, A. and Nicolet, J. (1998) Detection of alpha- and epsilon-toxigenic Clostridium perfringens Type D in sheep and goats using a DNA amplification technique (PCR). Lett. Appl. Microbiol., 26(5): 382-386.

22. Redostitis, O.M., Gay, C.C., Hinchcliff, K.H. and Constable, P.D. (2007) Veterinary Medicine. $10^{\text {th }}$ ed. Saunders Elsevier, London.

23. Jabbari, A.R., Tekyei, F., Esmaeilzad, M. and Langroudi, R.P. (2012) Occurrence of Beta2 toxigenic Clostridium perfringens isolates with different toxin types in Iran. Arch. Razi Inst., 67(2): 133-137.

24. Uzal, F.A., Freedman, J.C., Shrestha, A., Theoret, J.R., Garcia, J., Awad, M.M, Adams, V., Moore, R.J., Rood, J.I. and McClane, B.A. (2014) Towards an understanding of the role of Clostridium perfringens toxins in human and animal disease. Future Microbiol., 9(3): 361-377.

25. Baums, C.G., Schotte, U., Amtsberg, G. and Goethe, R. (2004) Diagnostic multiplex PCR for toxin genotyping of Clostridium perfringens isolates. Vet. Microbiol., 100(1-2): 11-16.

$* * * * * * * *$ 